\title{
The Use of Supplements among Adults in Selected Gymnasium in Kuala Lumpur, Malaysia
}

\section{Sedek R*, Li TZ, Kambli NZ and Kasim ZM}

Food Science Programme, School of Chemical Sciences and Food Technology, Faculty of Science and Technology, Universiti Kebangsaan Malaysia, Bangi, Selangor, Malaysia

*Corresponding author: Razalee Sedek, Food Science Programme, School of Chemical

\section{Research Article}

Volume 3 Issue 4

Received Date: July 31, 2018

Published Date: August 10, 2018

Sciences and Food Technology, Faculty of Science and Technology, Universiti Kebangsaan Malaysia, 43600 Bangi, Selangor, Malaysia, Email: razalee@ukm.edu.my

\section{Abstract}

The use of supplement is prevalent among Malaysians especially athletes and gym users. However, the study on the use of supplements among people exercising in the gym is rarely carried out in Malaysia. The aim of this study was to assess supplement use among adults who exercise in gyms in Setapak, Kuala Lumpur. This study also aimed to compare sociodemographic characteristics between supplement users and non-users. A total of 315 gym users $(79.0 \%$ male and $21.0 \%$ female), with a mean age of $27.1 \pm 7.8$ years participated in this study. Data collection was carried out in five gyms located in Setapak, Kuala Lumpur. Anthropometric measurement of body weight and height of the respondents were taken. Sociodemographic information and supplement use were obtained using questionnaires. This study found that $66.3 \%$ of respondents were supplement users. Protein shake (73.7\%), vitamin C $(72.4 \%)$ and whey protein $(68.3 \%)$ were the most popular choices among supplement users. Internet (76.2\%), friends (47.9\%) and coaches $(35.2 \%)$ were primary sources of supplement information. There were significant association between body mass index category $(\mathrm{p}=0.020)$, age group $(\mathrm{p}=0.037)$, gender $(\mathrm{p}<0.001)$ and race $(\mathrm{p}=0.027)$ with supplement use status. In conclusion, prevalence of supplement use among gym users was high. Therefore, it is crucial to disseminate precise and scientific based on information on the health benefits and risks of supplement to the s gym users to avoid inappropriate use of supplement.

Keywords: Adult; Gyms; Supplements

\section{Introduction}

The supplement industry is considered as one of the growing industries in the world that contribute significantly to the global economy. One of the biggest trends in the healthcare industry is that now focuses on health and look for alternative medicines including supplements, Nutraceutical and functional foods to 
improve their lifestyle [1]. In Malaysia, supplements are categorized under the pharmaceutical industry as a health supplement and dietary supplement that includes traditional medicines. Supplements are usually available in a variety of forms including tablets, capsules, powders, or pills.

According to the Dietary Supplement Health and Education Act of 1994 (USA 1994) [2], the term dietary supplement is a product (other than tobacco) intended to supplement the diet that contains one or more dietary ingredients such as vitamin, mineral, herb or other botanical, amino acid, a dietary substance to supplement the diet by increasing the total dietary intake, metabolite, constituent, extract, or combination of any ingredient. There is no regulation on supplements in Malaysia. Supplements are widely available in various places such as pharmacy and most of the supplements are sold without a prescription. Some studies have shown that most people that use supplements not get medical advice before taking Individuals who consume supplements are often those involved in sports and physical activities [3]. Besides that, supplements can increase daily intake of vitamins and minerals and prevent chronic diseases [4]. Among the main causes of active individuals taking supplements are to build muscles, increase strength, prevent future illness and improve performance in sports $[5,6]$. Proteins are the most widely used supplements taken by those who exercise in commercial gyms [7].

There are various studies that report on the use of supplements among athletes. However, the study on the supplement use among people exercising in the gym is rarely carried out in Malaysia. This study can be used by the health professionals to educate the population and provide information on supplements intake among gym members. This is because some individuals may obtain information on the use of supplement from less qualified and non-healthcare sources. The aim of this study is to assess the use of supplements and identify the sources of supplement information among adults who exercise at gymnasium in Setapak, Kuala Lumpur. This study is also aimed to determine the association between sociodemographic characteristics, body mass index (BMI) with the status of use of supplements.

\section{Materials and Methods}

\section{Sampling and Study Location}

This cross-sectional study was conducted at fiveselected gymnasium in Setapak, Kuala Lumpur that was selected randomly. This study involved a total of 344 respondents aged between 19 and 60 years old, respondents exercise at gymnasium at least twice a week. Estimated sample size was calculated by using Daniel method (1999) [8].

\section{Data Collection}

Anthropometric measurements cluded weight and height. Body weight was measured to the nearest $0.1 \mathrm{~kg}$ using Tanita HD-312 Digital Balance (Tanita Corp., Tokyo, Japan). The height of the respondents was measured to the nearest $0.1 \mathrm{~cm}$ using SECA 208 body meter (SECA, Hamburg, Germany). Body mass index (BMI) was determined by dividing weight $(\mathrm{kg})$ by height $\left(\mathrm{m}^{2}\right)$. A questionnaire was used to collect the data on sociodemographic information of respondents included age, gender, race, education level and household income as well as to collect data on the use of supplements including types of supplements and sources of supplements.

\section{Ethical Approval}

This study obtained an ethical approval from Universiti Kebangsaan Malaysia Research Ethical Committee with references number UKM PPI/8/JEP2017-628.

\section{Statistical Analysis}

Data was analyzed using Statistical Package for Social Sciences (SPSS) version 22.0 (SPSS Inc, Chicago, IL, USA). Statistical test used were descriptive statistics, independent t-test and chi- square test. Descriptive statistics including mean, frequency, percentages, and standard deviation were tabulated. Independent t-test was used to determine significant differences of mean of anthropometric measurements between male and female. Chi-square test was used to determine the association between socio demo graphic characteristics and BMI with supplements use status. Differences were considered statistically significant at $\mathrm{p}<0.05$ for all analysis.

\section{Results and Discussion}

\section{Anthropometric Characteristics}

Three hundred and fifteen respondent respondents were involved in this study. Anthropometric measurement included weight, height and BMI. (Table 1) shows the physical characteristics of the respondents by gender. Independent t-test shows that mean of weight, height and BMI for male was significantly higher than female. 


\section{Food Science and Nutrition Technology}

\begin{tabular}{|c|c|c|c|c|c|}
\hline \multirow{2}{*}{ Antrophometric characteristics } & \multicolumn{4}{|c|}{ Mean \pm SD } & \multirow{2}{*}{ P value } \\
\cline { 2 - 5 } & \multicolumn{2}{|c|}{ Male (n=249) } & \multicolumn{2}{|c|}{ Female (n=66) } & \\
\hline Weight $(\mathrm{kg})$ & $74.2 \pm$ & 11.8 & $59.6 \pm$ & 12.7 & $<0.001^{* * *}$ \\
\hline Height $(\mathrm{m})$ & $1.7 \pm$ & 0.1 & $1.6 \pm$ & 0.1 & $<0.001^{* * *}$ \\
\hline Body mass index $\left(\mathrm{kg} / \mathrm{m}^{2}\right)$ & $24.9 \pm$ & 3.6 & $22.9 \pm$ & 4.8 & $<0.001^{* * *}$ \\
\hline
\end{tabular}

Table 1: Physical characteristics of respondents by gender.

*** There are significant differences between male and female $(\mathrm{p}<0.001)$

Table 2 shows distribution of respondents according to classification of BMI and supplements used status. Overall, according to classification of BMI, majority of respondents were normal $(55.6 \%)$ followed by overweight (33.0\%), underweight $(4.1 \%)$ and obese (7.3\%). The prevalence of overweight or obese was high because some individual have a BMI above $25 \mathrm{~kg} / \mathrm{m}^{2}$ may be due to high muscle mass but not due to the weight of excess fat. Chi-square test shows that there was a significant association between classification of BMI and supplements use status $(\mathrm{p}=0.020)$. A total of $38.5 \%$ of respondents that categorized as underweight were less likely to take dietary supplements. While, $62.9 \%$ respondents that categorized as normal, $76.0 \%$ overweight and $65.2 \%$ obese were likely more tend to take dietary supplements. The prevalence of normal, overweight and obese that use dietary supplements in this study are much higher compared to the results of the National Health and Nutrition Examination Survey (NHANES) 2003-2006 in United States that shows 56\% respondents categorized as normal, $57 \%$ overweight and $48 \%$ obese use dietary supplements [9].

\begin{tabular}{|c|c|c|c|c|c|c|c|c|}
\hline \multirow{3}{*}{$\begin{array}{c}\text { BMI Classification } \\
\left(\mathrm{kg} / \mathrm{m}^{2}\right)\end{array}$} & \multirow{2}{*}{\multicolumn{2}{|c|}{\begin{tabular}{|c|} 
Supplement users \\
$(n=178)$ \\
\end{tabular}}} & \multirow{2}{*}{\multicolumn{2}{|c|}{$\begin{array}{c}\text { Non supplement users } \\
(n=71) \\
\end{array}$}} & \multirow{2}{*}{\multicolumn{2}{|c|}{ Overall (N=315) }} & \multirow{3}{*}{$\chi^{2}$} & \multirow{3}{*}{$P$ value } \\
\hline & & & & & & & & \\
\hline & $\mathbf{n}$ & $\%$ & $\mathbf{n}$ & $\%$ & $\mathbf{n}$ & $\%$ & & \\
\hline $\begin{array}{c}\text { Underweight } \\
(<18.5)\end{array}$ & 5 & 38.5 & 8 & 61.5 & 13 & 4.1 & 9.801 & $0.020^{*}$ \\
\hline Normal (18.5-24.9) & 110 & 62.9 & 65 & 37.1 & 175 & 55.6 & & \\
\hline $\begin{array}{c}\text { Overweight } \\
(25.0-29.9)\end{array}$ & 79 & 76 & 25 & 24 & 104 & 33 & & \\
\hline Obese $(\geq 30.0)$ & 15 & 65.2 & 8 & 34.8 & 23 & 7.3 & & \\
\hline
\end{tabular}

Table 2: Distribution of respondents according to classification of body mass index (BMI) and supplements use status.

* There are significant association between BMI classification with supplements use status at $(\mathrm{p}<0.05)$

Supplements Use According to Socio- tendency of supplements used by gym users increases and Demographic Characteristics of Respondents

The supplements used status based sociodemographic characteristics of the respondents are described in Table 3. A total of 315 respondents were involved in this study. Overall, $66.3 \%$ of the respondents in this study are supplement users. As supplements aim to improve physical performance or body composition, the becoming a common practice. The prevalence of supplements used in this study were higher compared to study on respondents that exercise at gymnasium in Lembah Klang, Malaysia (41\%) and Pulau Pinang, Malaysia (51.2\%) but lower compared to study at gymnasium in Tehran, Iran (66.7\%) [10] and New York $(84.7 \%)[11]$.

\begin{tabular}{|c|c|c|c|c|c|c|c|c|}
\hline \multirow{3}{*}{$\begin{array}{l}\text { Demographic } \\
\text { profile }\end{array}$} & \multirow{2}{*}{\multicolumn{2}{|c|}{$\begin{array}{c}\text { Supplement users } \\
(n=209)\end{array}$}} & \multirow{2}{*}{\multicolumn{2}{|c|}{\begin{tabular}{|c|} 
Non supplement users \\
$(\mathrm{n}=106)$ \\
\end{tabular}}} & \multirow{2}{*}{\multicolumn{2}{|c|}{$\begin{array}{c}\text { Overall } \\
(N=315)\end{array}$}} & \multirow{3}{*}{$\chi^{2}$} & \multirow{3}{*}{$P$ value } \\
\hline & & & & & & & & \\
\hline & $\mathbf{n}$ & $\%$ & $\mathbf{n}$ & $\%$ & $\mathbf{n}$ & $\%$ & & \\
\hline Overall & 209 & 66.3 & 106 & 33.7 & & & & \\
\hline Ages (years) & & & & & & & 4.356 & $0.037^{*}$ \\
\hline$<30$ & 140 & 62.8 & 83 & 37.2 & 223 & 70.8 & & \\
\hline$\geq 30$ & 69 & 75 & 23 & 25 & 92 & 29.2 & & \\
\hline
\end{tabular}




\section{Food Science and Nutrition Technology}

\begin{tabular}{|c|c|c|c|c|c|c|c|c|}
\hline Gender & & & & & & & 14.045 & $<0.001^{* * *}$ \\
\hline Male & 178 & 71.5 & 71 & 28.5 & 249 & 79 & & \\
\hline Female & 31 & 47 & 35 & 53 & 66 & 21 & & \\
\hline Race & & & & & & & 7.224 & $0.027^{*}$ \\
\hline Malay & 110 & 73.8 & 39 & 26.2 & 149 & 47.3 & & \\
\hline Chinese & 79 & 59 & 55 & 41 & 134 & 42.5 & & \\
\hline Indian & 20 & 62.5 & 12 & 37.5 & 32 & 10.2 & & \\
\hline Education level & & & & & & & 0.308 & 0.857 \\
\hline Secondary school & 27 & 62.8 & 16 & 37.2 & 43 & 13.7 & & \\
\hline $\begin{array}{c}\text { College or university } \\
\text { students }\end{array}$ & 77 & 66.4 & 39 & 33.6 & 116 & 36.8 & & \\
\hline $\begin{array}{c}\text { College or university } \\
\text { graduate }\end{array}$ & 105 & 67.3 & 51 & 32.7 & 156 & 49.5 & & \\
\hline \begin{tabular}{|c|}
$\begin{array}{c}\text { Household income } \\
\text { (RM) }\end{array}$ \\
\end{tabular} & & & & & & & 4.123 & 0.127 \\
\hline$<3000$ & 113 & 62.8 & 67 & 37.2 & 180 & 57.1 & & \\
\hline 3000-5999 & 65 & 67.7 & 31 & 32.3 & 96 & 30.5 & & \\
\hline$\geq 6000$ & 31 & 79.5 & 8 & 7.5 & 39 & 12.4 & & \\
\hline
\end{tabular}

Table 3: Supplements use status according to Socio- demographic characteristics.

* There are significant association between ages and race with supplements use status at $\mathrm{p}<0.05$

$* * *$ There are significant association between gender with supplements uptake status at $\mathrm{p}<0.0$

A total of 223 respondents were age less than 30 years old $(70.8 \%)$ and 92 respondents aged 30 years and above (29.2\%) were involved in this study. It was observed that percentage of supplement users with age of 30 years and above $(75.0 \%)$ was higher compared to supplement user's age less than 30 years old (62.8\%). Chi-square test shows that there are significant association between age with supplements use status $(\mathrm{p}=0.037)$. The study of Goston and Correia (2010) [12] reported inconsistent results where supplement users are younger than nonsupplement users $(\mathrm{p}<0.01)$.

Besides that, 249 male (79.0\%) and 66 female (21.0\%) were involved in this study. Comparison between gender shows that male respondents $(71.5 \%)$ were more likely to consume supplements than female respondents $(47.0 \%)$ were. The result shows that there is a significant association between gender and supplements used status $(\mathrm{p}<0.001)$. The study of Goston and Correia (2010) [12] reported similar result where male use more supplements compared to female $(44.6 \%, 28.1 \%$ respectively; $p<0.01)$. However, the results of this study was different from study reported by Mazlan (1990) [13] who found that prevalence of supplements users among students at Universiti Putra Malaysia was higher among female (14.9\%) compared to male (9.7\%).
The respondents comprised three race, whereby 149 are Malays (47.3\%), followed by 134 Chinese (42.5\%) and India $(10.2 \%)$. The result shows that there is a significant association between race and supplements use status $(\mathrm{p}=0.027)$. Prevalence of supplement users among the Muslims (73.8\%) was higher compared to Chinese respondents (59.0\%) and Indian respondents are (62.5\%). Nevertheless, the study by Al - Naggar and Chen (2011) [14] reported contrasting results where race do not influence the practice of consuming vitamin-mineral supplements significantly among students of Management and Science University, Malaysia.

Majority of the respondents (57.1\%) had household income of less than RM 3000 in a month, followed by household income between RM 3000 to RM 6000 in a month (30.5\%) and over RM6000 in a month (12.4\%). The results show that there were no significant association between supplements use status with household income ( $p>0.05)$. However, the study by $\mathrm{Al}$ Naggar and Chen (2011) [14] reported there was significant association between household income with intake of vitamin- mineral supplements status among students of Management and Science University, Malaysia. 


\section{Types of Supplements}

Figure 1 shows several types of supplements consumed by the respondents. Overall, there are ten types of supplements that are most popular choices among supplement users including protein shake $(73.7 \%)$, vitamin C $(72.4 \%)$, whey protein $(68.3 \%)$, energy drink (67.0\%), multivitamin (65.1\%), branched chain amino acid (BCAA) (64.1\%), Vitamin $\mathrm{E}$ and protein powders (63.2\% respectively) as well as protein bar and Vitamin B complex (59.7\% respectively). Protein is a supplement that is widely consumed as reported in previous studies such as $28 \%$ of gymnasium users use protein in Sevilla, Spanish [15], 42.3\% in New York City [11] and 58\% in Belo Horizonte, Brazil [12]. Study at gymnasium in Pulau Pinang, Malaysia reported similar result whereby protein supplements are the most popular choice (76.2\%) [16]. Nevertheless, study at the Klang Valley, Malaysia (Wong \& Mohd Nasir 2010) [17] shows that vitamin supplements was most consumed by fitness club members (59.4\%) and only $28.1 \%$ subject consumed protein supplements.

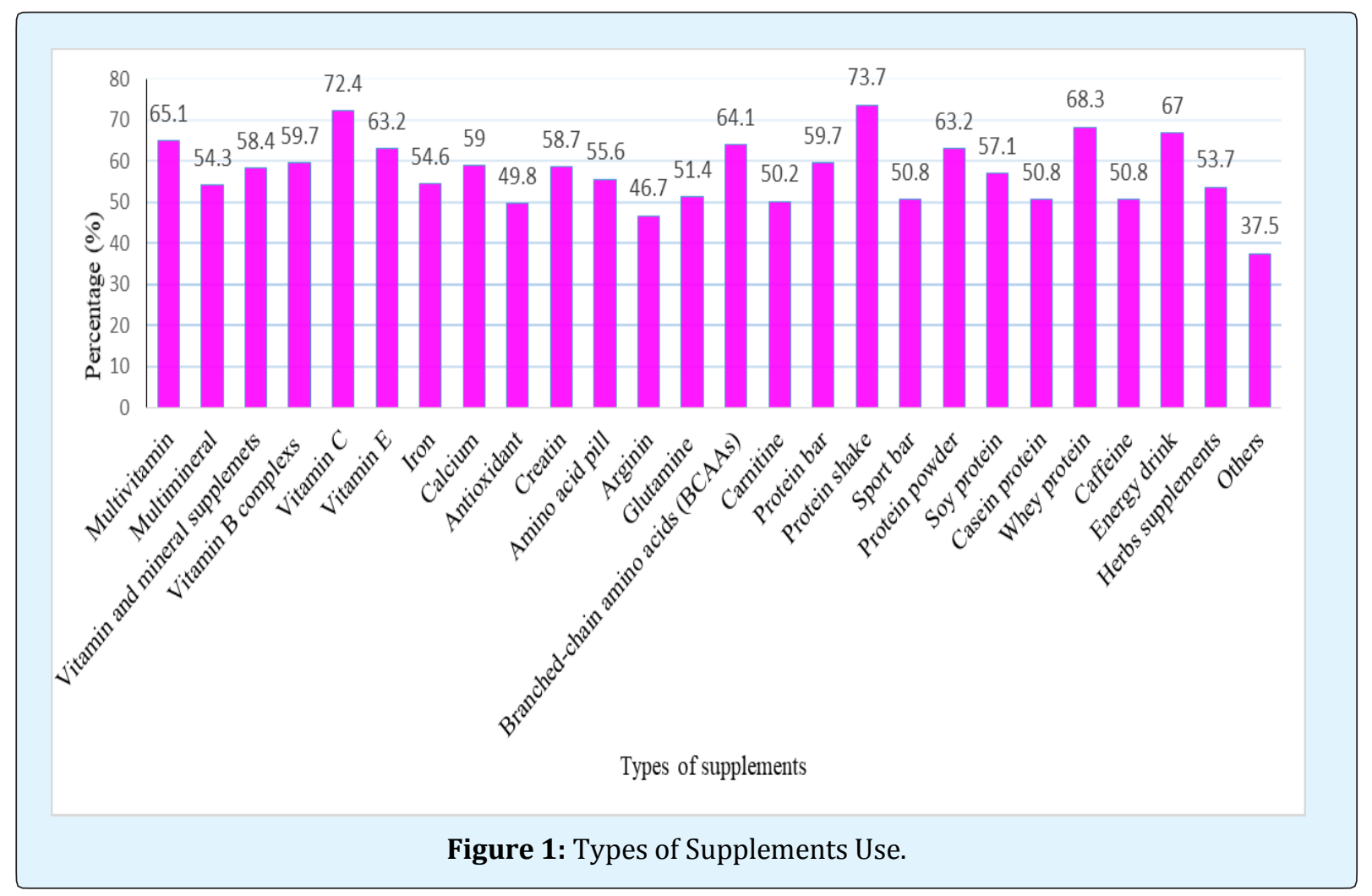

Apart from that, respondents in this study also commonly used multivitamin and multi-mineral supplements such as vitamin C (72.4\%), multivitamin (65.1\%) and vitamin E (63.2\%) were Multivitaminmineral supplements were also widely used among respondents in the previous studies [10]. Furthermore, vitamin and mineral supplements are often used in training $[18,12]$.

\section{Sources of Supplement Information}

Figure 2 shows sources of supplement information. Internet $(76.2 \%)$, friends $(47.9 \%)$, coaches $(35.2 \%)$, doctors (19.7\%) and magazines (19.4\%) were primary sources of supplement information. The study of Bianco et al. (2014) [19] at a gymnasium in Palermo, Italy shows that $37.0 \%$ of respondents refer to coaches as sources of supplement information and $11.0 \%$ refers to friends. According to Fox and Rainie (2000) [20], almost 80\% athlete obtained information about supplements from "questionable" sources including media, internet, friends and coaches. Although media information cannot be clinically confirmed, $52 \%$ of users are found to believe that health information on the internet is credible through Pew Internet and the American Life Project Report. 


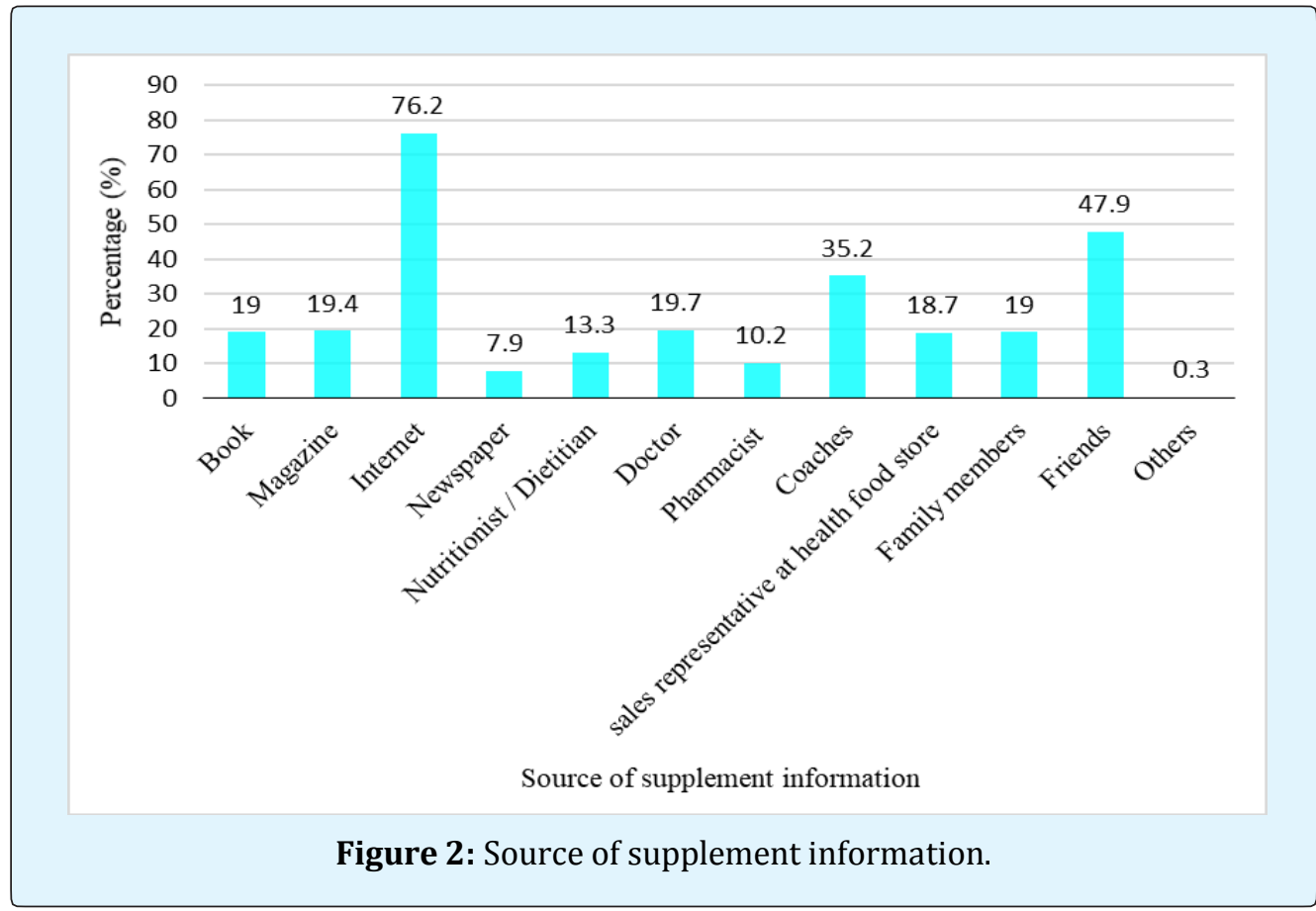

In another studies, coaches are described as the most trusted professional for the sources of supplement information [21,22]. However, advices provided by coaches usually are inaccurate, inappropriate, or may potentially damage because most of the coaches have minimal knowledge in sports nutrition. Consultation with medical professionals, including medical and dietitian experts, are practiced at a lower level in the sport environment including in this study at $13.3 \%$. Apart from that, the study by Rocha and Pereira (1998) [23] shows that most athletes (78\%) do not get their supplements information from nutritionists.

\section{Conclusion}

In conclusion, prevalence of supplement use among gym users was high. There were significant association between BMI category, age group, gender and race with supplements use status. Besides that, protein shake, vitamin $\mathrm{C}$, whey protein and energy drink were the most popular choices among the supplement users. Internet, friends and coaches were primary sources of supplement information.

\section{Acknowledgement}

The authors would like to thank to the managers from Beast Gym, Power work Fitness, Ultimate Gym, Megafit Centre and Underground Fitness for granting permission to conduct this study and most importantly to all respondents from the gym. Appreciation to the School of Chemical Sciences and Food Technology, Faculty of Science and Technology, UKM for providing support to conduct this

\section{References}

1. Greger JL (2001) Dietary supplement use: Consumer characteristics and interests. Journal of Nutrition 131(4): 1339-1343.

2. United States of America (USA) (1994) Dietary Supplement Health and Education Act of 1994.

3. Maughan RJ, King DS, Lea T (2004) Dietary supplements. Journal of Sports Sciences 22(1): 95113.

4. Archer SL, Stamler J, Moag-Stahlberg A, Van Horn L, Garside D, et al. (2005) Association of dietary supplement use with specific micronutrient intakes among middle-aged American men and women: The INTERMAP Study. Journal of the American Dietetic Association 105(7): 1106-1114.

5. Sundell J, Hulmi J, Rossi J (2011) Whey protein and creatine as nutritional supplements. Duodecim 127(7): 700-705. 
6. Wolfe RR (2000) Protein supplements and exercise. The American Journal of Clinical Nutrition 72(2): 551S-557S.

7. Bianco A, Mammina C, Paoli A, Bellafiore M, Battaglia G, et al. (2011) Protein supplementation in strength and conditioning adepts: Knowledge, dietary behavior and practice in Palermo, Italy. Journal of the International Society of Sports Nutrition 8(25): 1-6.

8. Daniel WW (1999) Biostatistics: A Foundation for Analysis in the Health Sciences. $7^{\text {th }}$ (Edn.).

9. Bailey RL, Gahche JJ, Lentino CV, Dwyer JT, Engel JS, et al. (2011) Dietary supplement use in the United States, 2003-2006. Journal of Nutrition 141(2): 261266.

10. Saeedi P, Mohd Taib MN, Hazizi AS, Vafa MR, Foroushani AR (2013) Nutritional supplement use among fitness club participants in Tehran, Iran. Appetite 60(1): 20-26.

11. Morrison LJ, Gizis F, Shorter B (2004) prevalent use of dietary supplements among people who exercise at a commercial gym. International Journal of Sport Nutrition and Exercise Metabolism 14(4): 481-492.

12. Goston JL, Correia MI (2010) Intake of nutritional supplements among people exercising in gyms and influencing factors. Nutrition 26(6): 604-611.

13. Mazlan Y (1990) Vitamin use and beliefs among students at a Malaysian university. Journal of the Royal Society of Health 110: 132-134.

14. Al-Naggar RA, Chen R (2011) Prevalence of vitaminmineral supplements use and associated factors among young Malaysians. Asian Pacific Journal of Cancer Prevention 12(4): 1023-1029.

15. Oliver AJ, León MT, Hernández EG (2008) Statistical analysis of the consumption of nutritional and dietary supplements in gyms. Archivos Latinoamericanos De Nutricion 58(3): 221-227.
16. Loh SY, Hazizi AS (2015) Factors associated with nutritional supplement use among exercisers in a selected gym in Penang Island. 30 th Scientific Conference of the Nutrition Society of Malaysia. Renaissance Hotel, Kuala Lumpur.

17. Wong LH, Mohd Nasir MT (2010) Factors associated with dietary supplement use among fitness club members in Klang Valley. $25^{\text {th }}$ Scientific Conference of the Nutrition Society of Malaysia. Crowne Plaza Mutiara Hotel, Kuala Lumpur.

18. El Khoury D, Antoine-Jonville S (2012) Intake of nutritional supplements among people exercising in gyms in Beirut city. Journal of Nutrition and Metabolism 2012: 1-12.

19. Bianco A, Mammina C, Thomas E, Bellafiore $M$, Battaglia G, Moro T, Paoli A, Palma A (2014) Protein supplementation and dietary behaviours of resistance trained men and women attending commercial gyms: A comparative study between the city centre and the suburbs of Palermo, Italy. Journal of the International Society of Sports Nutrition 11(30): 1-6.

20. Fox S, Rainie L (2000) The Online Health Care Revolution: How the Web Helps Americans Take Better Care of Themselves. Washington: The Pew Internet \& American Life Project.

21. Malinauskas BM, Overton RF, Carraway VG, Cash BC (2007) Supplements of interest for sport-related injury and sources of supplement information among college athletes. Advances in Medical Sciences 52: 5054 .

22. Molinero O, Márquez S (2009) Use of nutritional supplements in sports: Risks, knowledge, and behavioural-related factors. Nutricion Hospitalaria 24(2): 128-134.

23. Rocha LP, Pereira MVL (1998) Use of nutritional supplements by respondents enrolled inphysical fitness programs. Brazilian Journal of Nutrition 11: 76-82. 